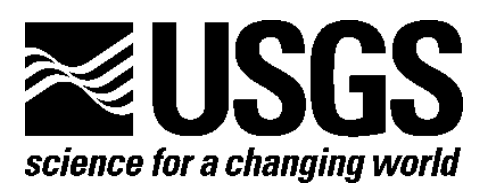

\title{
A Composite Depth Scale for Sediments from Crevice Lake, Montana
}

By J.G. Rosenbaum, G. Skipp, J. Honke, and C. Chapman

Open-File Report 2009-1277

U.S. Department of the Interior

U.S. Geological Survey 


\section{U.S. Department of the Interior \\ KEN SALAZAR, Secretary}

\section{U.S. Geological Survey \\ Marcia K. McNutt, Director}

U.S. Geological Survey, Reston, Virginia: 2010

For product and ordering information:

World Wide Web: http://www.usgs.gov/pubprod

Telephone: 1-888-ASK-USGS

For more information on the USGS-the Federal source for science about the Earth,

its natural and living resources, natural hazards, and the environment:

World Wide Web: http://www.usgs.gov

Telephone: 1-888-ASK-USGS

Suggested citation:

Rosenbaum, J.G., Skipp, G., Honke, J., and Chapman, C., 2010, A composite depth scale for sediments from Crevice Lake, Montana: U.S. Geological Survey Open-File Report 2009-1277, 5 p.

Any use of trade, product, or firm names is for descriptive purposes only and does not imply endorsement by the U.S. Government.

Although this report is in the public domain, permission must be secured from the individual copyright owners to reproduce any copyrighted material contained within this report. 


\section{Contents}

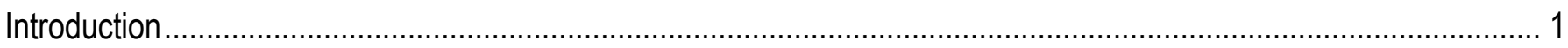

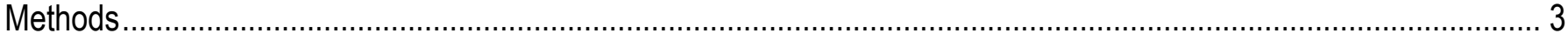

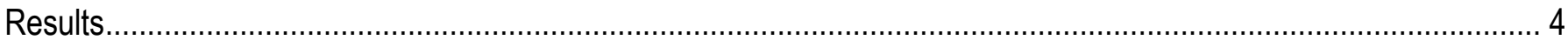

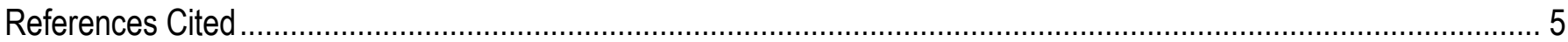

\section{Figures}

1. Location of Crevice Lake 1

2. Freeze core of varved sediments from Crevice Lake. 2

3. Composite section of sediment from Crevice Lake, Montana (in separate file)

\section{Tables}

1. Percussion Cores Taken from Crevice Lake, Montana......................................................................................... 3

2. Depth Adjustments for Converting Depth in Segment to Depth in Composite Section....................................... 4 


\section{Conversion Factors}

SI to Inch/Pound

\begin{tabular}{lcll}
\hline & Multiply & & To obtain \\
\hline & Length & \\
\hline centimeter $(\mathrm{cm})$ & 0.3937 & inch (in.) & \\
meter $(\mathrm{m})$ & 3.281 & foot (ft) & \\
\hline & Area & \\
\hline hectare (ha) & 2.471 & acre \\
\hline
\end{tabular}




\title{
A Composite Depth Scale for Sediments from Crevice Lake, Montana
}

\author{
By J.G. Rosenbaum, G. Skipp, J. Honke, and C. Chapman
}

\section{Introduction}

As part of a study to derive records of past environmental change from lake sediments in the western United States, a set of cores was collected from Crevice Lake, Montana, in late February and early March 2001. Crevice Lake (latitude 45.000N, longitude 110.578W, elevation 1,713 meters (m)) lies adjacent to the Yellowstone River at the north edge of Yellowstone National Park (fig. 1). The lake is more than $31 \mathrm{~m}$ deep and has a surface area of 7.76 hectares. The combination of small surface area and significant depth promotes anoxic bottom-water conditions that preserve annual laminations (varves) in the sediment.

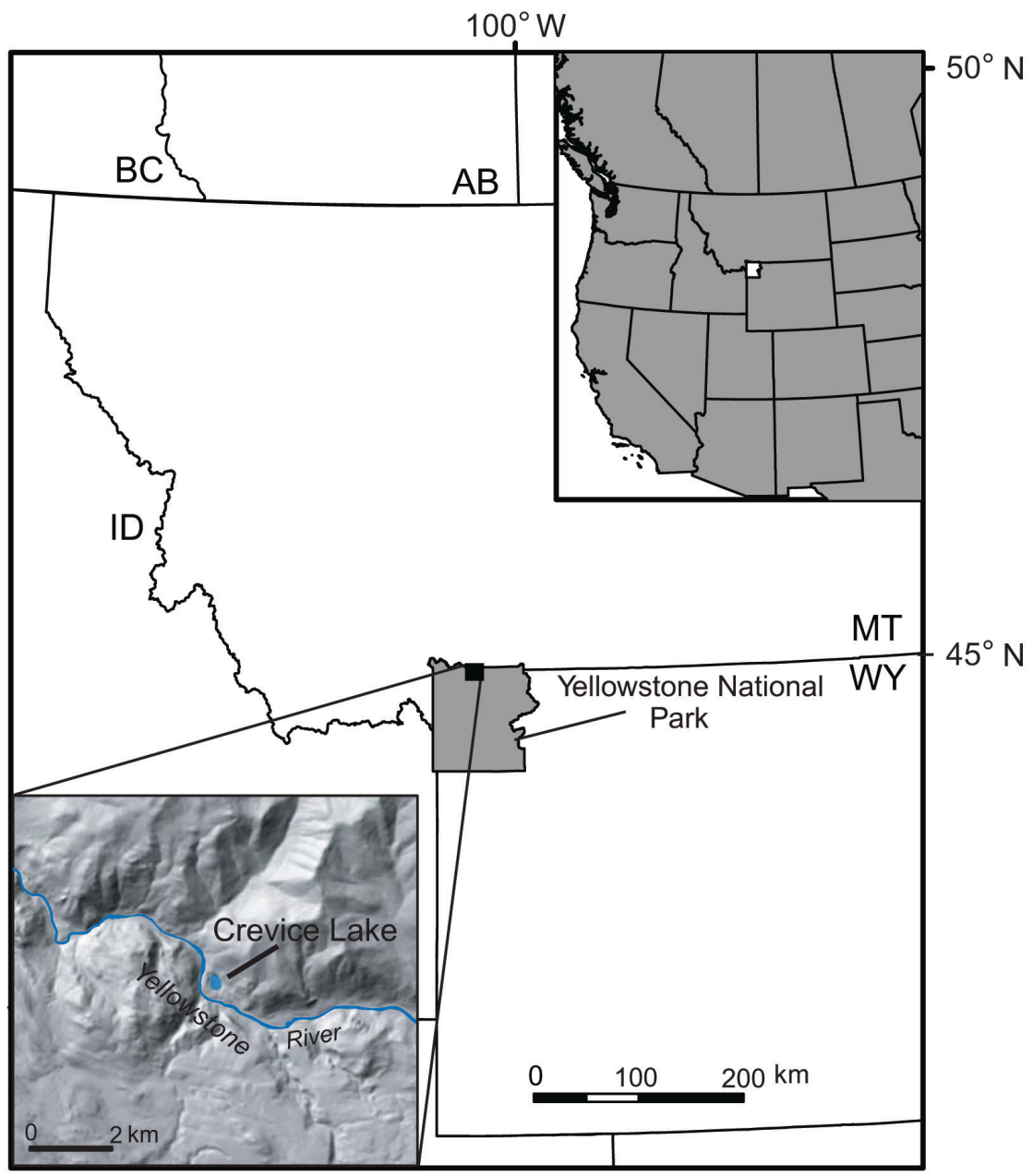

Figure 1. Location of Crevice Lake. 
Three types of cores were collected through the ice. The uppermost sediments were obtained in freeze cores (Glew and others, 2001) that preserved the sediment water interface (fig. 2). Two sites were cored with a 5 -centimeter $(\mathrm{cm})$ diameter Livingstone corer (Glew and others, 2001). Five cores were taken with a 2-m-long percussion piston corer. The percussion core (manufactured by UWITEC) uses a plastic core liner with an inside diameter of $9 \mathrm{~cm}$. Coring was carried out at two sites. Cores A and $\mathrm{B}$ were taken from site 1 and cores $\mathrm{C}, \mathrm{D}$, and $\mathrm{E}$ from site 2 (table 1). Cores $\mathrm{A}-\mathrm{D}$ each consist of three overlapping sections. Core $\mathrm{E}$ is made up of a single section. Because of the relatively large diameter of the percussion cores, samples from these cores were used for a variety of analyses including pollen, charcoal, diatoms, stable isotopes, organic and inorganic carbon, elemental analyses, and magnetic properties. As explained below, portions of various percussion core segments were spliced to form a composite section. The purposes of this report are to provide a depth scale for that composite section and to establish a method of conversion between sample nomenclature and that depth scale.

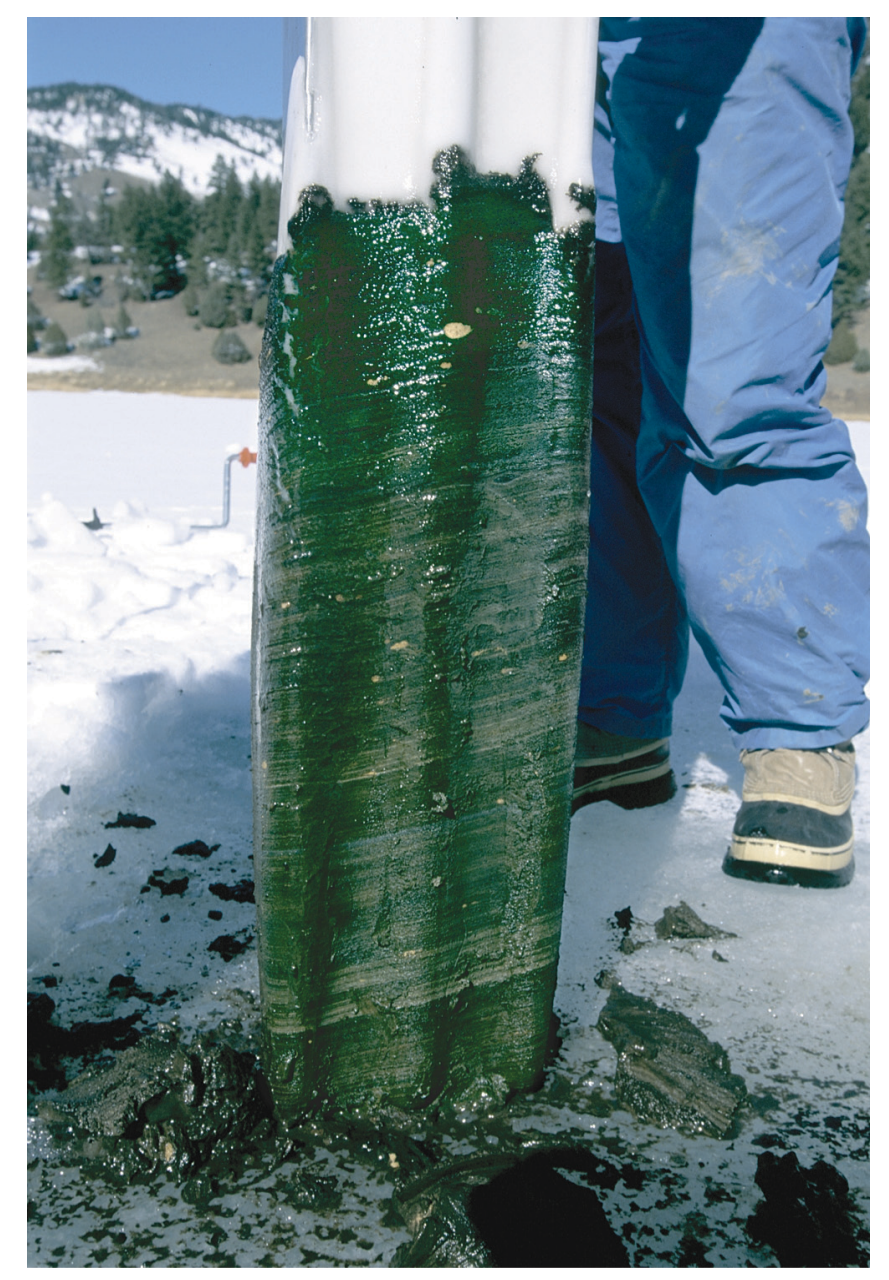

Figure 2. Freeze core of varved sediments from Crevice Lake. 
Table 1. Percussion Cores Taken from Crevice Lake, Montana.

\begin{tabular}{|c|c|c|c|c|c|c|}
\hline $\begin{array}{l}\text { Site } \\
\text { number }\end{array}$ & $\begin{array}{c}\text { Water } \\
\text { depth } \\
\text { (meter) }\end{array}$ & Core & Location 1 & Segment & $\begin{array}{l}\text { Approximate cored } \\
\text { interval (meters } \\
\text { below lake surface) }\end{array}$ & $\begin{array}{l}\text { Recovery } \\
\text { (meter) }\end{array}$ \\
\hline \multirow[t]{4}{*}{1} & \multirow[t]{4}{*}{27.57} & \multirow[t]{2}{*}{ CV01A } & \multirow{2}{*}{$\begin{array}{l}45.00043 \mathrm{~N} \\
110.57827 \mathrm{~W}\end{array}$} & 1 & $27.87-29.93$ & 1.91 \\
\hline & & & & $\begin{array}{l}2 \\
3\end{array}$ & $\begin{array}{l}29.93-31.99 \\
31.99-33.27\end{array}$ & $\begin{array}{l}1.90 \\
0.81\end{array}$ \\
\hline & & \multirow[t]{2}{*}{ CV01B } & \multirow[t]{2}{*}{$\begin{array}{l}2 \text { meters southwest of } \\
\text { CV01A }\end{array}$} & 1 & $28.72-30.66$ & 1.79 \\
\hline & & & & $\begin{array}{l}2 \\
3\end{array}$ & $\begin{array}{l}30.66-32.72 \\
31.66-33.72\end{array}$ & $\begin{array}{l}1.65 \\
1.56\end{array}$ \\
\hline \multirow[t]{6}{*}{2} & \multirow[t]{6}{*}{27.37} & \multirow[t]{2}{*}{ CV01C } & \multirow[t]{2}{*}{$\begin{array}{c}45.00057 \mathrm{~N} \\
110.57862 \mathrm{~W}\end{array}$} & 1 & $27.57-29.63$ & 1.90 \\
\hline & & & & $\begin{array}{l}2 \\
3\end{array}$ & $\begin{array}{l}29.63-31.69 \\
31.69-33.75\end{array}$ & $\begin{array}{l}1.63 \\
1.63\end{array}$ \\
\hline & & \multirow[t]{3}{*}{ CV01D } & \multirow[t]{2}{*}{$\begin{array}{l}1 \text { meter west of } \\
\text { CV01C }\end{array}$} & 1 & $28.57-30.63$ & 1.90 \\
\hline & & & & 2 & $30.63-32.69$ & 1.90 \\
\hline & & & \multirow{2}{*}{$\begin{array}{l}2 \text { meter south of } \\
\text { CV01D }\end{array}$} & 3 & $32.69-34.63$ & 1.70 \\
\hline & & CV01E & & 1 & $34.19-35.93$ & 1.55 \\
\hline
\end{tabular}

${ }^{1}$ Latitude and longitude from global positioning system; datum is World Geodetic System 84.

\section{Methods}

The percussion piston corer is suspended on a cable system and lowered through the water column. If coring is to begin below the sediment water interface, the piston remains locked in place at the lower end of the core barrel while the barrel is driven into the sediment by repeatedly dropping a hammer weight. At the desired depth, the piston is released and held at a fixed depth by a cable to the surface while the barrel is driven further into the sediment.

Sampling was done in two stages. An initial stage of sampling was carried out at the University of Nebraska. During that stage, the upper $99.8 \mathrm{~cm}$ of segment CV01A-1 was sliced into 289 specimens that were interpreted to represent the past 2,650 years (Whitlock and others, 2008). A second stage of sampling took place at the U.S. Geological Survey in Denver. During the second stage, the remaining core was split lengthwise, cleaned, described and photographed. For each segment except CV01A-1, scales for photographs and subsequent sampling were set so that $0 \mathrm{~cm}$ was aligned with the top of the plastic core liner (fig. 3, in separate file). The scale for segment CV01A-1 was arbitrarily set so that the top of the unsampled portion was at $77.5 \mathrm{~cm}$. For the second stage of sampling, sample names consist of core, segment, and interval on the scale (for example, C-2 77-77.5 is a sample from 77-77.5 cm within segment 2 of core C). Visual inspection of the sliced core shows that coring deformed the sediment to varying degrees. Laminae in some zones are nearly flat, whereas those in other zones are convex upward. Sampling by horizontal sectioning of severely deformed core is not desirable, therefore, a composite section was established to sample the entire cored section using the least deformed sediment (fig. 3).

To establish a composite section, core segments were first roughly aligned on the basis of depths from coring notes and then more precisely aligned by visually correlating distinctive features among various core segments (fig. 3). Depths estimated from coring notes have potential errors from 
uncertainties in initial field measurement and because of core loss and deformation. The features used for correlation include packages of rhythmically layered sediments (for example, in segments CV01A-1 and CV01B-1), an ash layer (at $1.80 \mathrm{~m}$ and $0.91 \mathrm{~m}$ in segments CV01B-1 and CV01C-2, respectively), and contacts between rhythmically layered and massive sediment (for example, near base of segment CV01C-2 and top of segment CV01B-2). After correlating cores, a composite section was established by incorporating the least deformed core in each stratigraphic interval.

\section{Results}

The presence of distinctive packages of rhythmically layered sediment allowed straightforward correlation among most core segments. The only questionable correlation used for transferring the composite section from one core segment to another occurs at the contact between a massive gray unit (above) and a brecciated unit (below). This contact was interpreted to occur at $1.28 \mathrm{~m}$ in CV01C-3, $0.38 \mathrm{~m}$ in CV01D-3, and $0.70 \mathrm{~m}$ in CV01B-3 (fig. 3).

Distinctive laminae in rhythmically layered sediments in the upper portion of core segment CV01A-1 (which was sampled at the University of Nebraska) were visually correlated with those in a freeze core that preserved the sediment water/interface. In this manner the top of segment CV01A-1 was determined to be $11.9 \mathrm{~cm}$ below the sediment/water interface. As stated previously, the upper 99.8 cm of segment CV01A-1 were sampled at the University of Nebraska during the first stage of sampling. The top of the portion of segment CV01A-1 sampled during the second phase at the USGS in Denver therefore is at a depth of $111.7 \mathrm{~cm}(11.9+99.8$; table 2$)$. The depth below lake floor of a horizon within the composite section is simply the cumulative thickness of sediment in the composite section sampled during the second phase plus $111.7 \mathrm{~cm}$ (fig. 3). For CV01A-1, the difference between 111.7 $\mathrm{cm}$ and the scale reading for the top of this segment $(78 \mathrm{~cm})$ yields an "adjustment" of $33.7 \mathrm{~cm}$ to convert scale readings to depths below lake floor. Similar adjustments were calculated in a sequential manner for each core segment used in the composite section (table 2).

Table 2. Depth Adjustments for Converting Depth in Segment to Depth in Composite Section.

\begin{tabular}{|c|c|c|c|c|}
\hline Core segment & $\begin{array}{c}\text { Transition from } \\
\text { segment }^{1}\end{array}$ & $\begin{array}{l}\text { Depth of transition } \\
\text { in composite } \\
\text { section } \\
\text { (centimeters below } \\
\text { lake floor) }\end{array}$ & $\begin{array}{l}\text { Scale reading of } \\
\text { transition in } \\
\text { segment } \\
\text { (centimeter) }^{1}\end{array}$ & $\begin{array}{c}\text { Adjustment to } \\
\text { composite depth } \\
\text { scale (centimeter) }\end{array}$ \\
\hline CV01A-1 & $\begin{array}{l}\text { Upper part of } \\
\text { CV01A-1 }\end{array}$ & 111.7 & 78.0 & 33.7 \\
\hline CV01B-1 & CV01A-1 & 212.7 & 80.0 & 132.7 \\
\hline CV01C-2 & CV01B-1 & 222.2 & 0.0 & 222.2 \\
\hline CV01B-2 & CV01C-2 & 372.7 & 13.0 & 359.7 \\
\hline CV01C-3 & CV01B-2 & 463.2 & 46.0 & 417.2 \\
\hline CV01D-3 & CV01C-3 & 545.2 & 38.5 & 506.7 \\
\hline CV01E-3 & CV01D-3 & 666.7 & 10.0 & 656.7 \\
\hline
\end{tabular}

${ }^{1}$ See figure 3.

${ }^{2}$ Add adjustment to scale reading to obtain depth below lake floor (blf) in composite section.

${ }^{3}$ See text. 


\section{References Cited}

Glew, J.R., Smol, J.P., and Last, W.M., 2001, Sediment core collection and extrusion, in Last, W.M., and Smol, J.P., eds., Tracking environmental change using lake sediments volume 1: Basin analysis, coring, and chronological techniques.: Boston, Kluwer Academic Publishers, p. 73-105.

Whitlock, C., Dean, W., Rosenbaum, J., Stevens, L., Fritz, S., Bracht, B., and Power, M., 2008, A 2,650-year-long record of environmental change from northern Yellowstone National Park based on a comparison of multiple proxy: Quaternary International, 188, p. 126-138. 